\title{
PLASMA COAGULATING AND NON-COAGULATING STAPHYLOCOCCUS SPP. IN SKIN SAMPLES FROM DOGS AND THEIR RESISTANCE TO ANTIBIOTICS
}

\author{
Žaneta Maželienè $\dot{1}^{1,2}$, Asta Aleksandravičienè ${ }^{1}$, Aušrinė Petrauskaite் \\ Ingrida Viliušiene $\dot{\mathbf{e}}^{1}$, Daiva Šakiene் $\dot{\mathbf{e}}^{1}$ \\ ${ }^{1}$ Kaunas University of Applied Sciences, Faculty of Medicine, Department of Medical Technologies \\ and Dietetics, ${ }^{2}$ Lithuanian University of Health Sciences, Institute of Microbiology and Virology
}

Keywords: Staphylococcus aureus, non-plasma coagulative Staphylococcus spp., prevalence, antibiotic resistance.

\begin{abstract}
Summary
Staphylococci are human and animal mucosal surface and skin commensals that can cause a variety of infections, such as purulent skin infections, otitis externa, pyoderma, urinary tract infections, and postoperative infections. Dog skin is one of the protective barriers for animals. However, dogs can have and transmit a variety of microorganisms on their skin, including staphylococci. Most studies have compared plasma coagulating and non-coagulating Staphylococcus spp. by dog breeds, sex, and coat length. The aim - to identify plasma coagulating and non-coagulating Staphylococcus spp. in skin samples from dogs and its resistance to antibiotics by place of residence. Staphylococci were detected in more than half of the samples tested, one third of which were plasma coagulating and the remaining two thirds were non-coagulating plasma. Plasma non-coagulating staphylococci were mainly increased among dogs living at home and plasma coagulating - among dogs living outdoors, the difference between these groups is statistically significant. Staphylococcus aureus was predominantly resistant to penicillin and clindamycin, while plasma non-coagulants were resistant to fusidic acid.
\end{abstract}

\section{Introduction}

Animal skin is one of their protective barriers. The skin is a complex ecosystem inhabited by many different microorganisms [2]. Bacteria are most commonly found on the surface of the skin, and their entire population is called a microbiota [3]. It has been found that the microbiota of dog skin varies greatly in different parts of the body. The innate and adaptive skin immune response can modify the skin microbiota, however the microbiota itself also promotes the development of the immune system. Bacterial colonization is determined by the ecology of the skin surface, which varies greatly depending on the topographical location, endogenous host factors and exogenous environmental factors [7].

The surface of canine epimers is dominated by four major bacterial families - Corynebacteriaceae, Propionibacteriaceae, Staphylococcaceae and Micrococcaceae [12]. Staphylococci are widespread in the environment and are Gram+, spherical (coca) shaped bacteria, which are arranged in irregular groups and belong to the family Staphylococcaceae [6]. They are non-spore forming, immobile, having a cell wall optional aneorobes [9]. Although staphylococci do not form spores, at rest they can remain viable for several months - in sputum, bedding, dust, and pus [1]. Due to this ability to adapt to the environment, Staphylococcal bacteria are a major concern treatment facilities due to the development of antibiotic-resistant strains, which increase the number of staphylococcal infections [11]. Staphylococci belonging to the family Staphylococcaceae are clinically divided into two groups: plasma coagulants - Staphylococcus aureus and non-coagulating plasma - Staphylococcus epidermidis, Staphylococcus saprophyticus, Staphylococcus lugdunensis, Staphylococcus warneri, Staphylococcus hominis, Staphylococcus simulans, Staphylococcus haemolyticus, Staphylococcus capitis, Staphylococcus pettenkoferi [4].

Plasma coagulating $S$. aureus usually forms gray or deep gold colonies. Staphylococci synthesize the enzyme catalase, this helps to distinguish them from streptococci. They also slowly ferment a lot of carbohydrates forming lactic acid (without gas), and pathogenic staphylococci synthesize many non-cellular substances [8]. They are spread by touch - from hands on objects, from objects on wounds or food, 
and air droplets [6]. Most staphylococci are spread by pus and dehydrated exudate, which is excreted from infected wounds, sputum and burns [1].

Studies have shown that Staphylococcus spp. most commonly found in dogs wet areas - in the folds of the armpits and groin. The inner ear cup has the greatest variety of bacteria, and in the anus at least, however, most different species of bacteria were found [2]. In most studies were compared plasma coagulating and non-coagulating Staphylococcus spp. according to the $\operatorname{dog}^{\text {'s }}$ breed, sex, coat length. Noted that they were not assessed on the basis of residence, this raised the question whether there is a difference between plasma coagulation and non-coagulation Staphylococcus spp. growth on the skin of dogs relative to their place of residence.

The aime of this study was to determine plasma coagulating and non-coagulating Staphylococcus spp. from in skin samples from dogs and their resistance to antibiotics.

\section{Research methodology}

The study identified plasma coagulating and non-coagulating Staphylococcus spp. on the skin of dogs and their resistance to antibiotics. Qualitative microbiological research was performed at Kaunas university, Department of Medical Technology and Dietetics, in a Microbiology laboratory according to occupational safety rules. All samples for dog skin smear, werw taken from the abdominal area with a sterile cotton swab into the transport medium „TRANSWAB ${ }^{\circledR “}$. Samples were tested no later than 48 hours after collection. Samples were stored at $+4^{\circ} \mathrm{C}$ until analysis.

Data analysis was performed using IBM SPSS Statistic software. Descriptive statistics (frequency), group comparison (CHI square), and relationship calculation (contingency factor) were used.

The microbiological study consisted of six stages sampling, medium preparation and quality control, primary inoculation of samples into the sampling medium, identification of microorganisms detected in the samples and eva-

Table 1. Sociodemographic indicators of the study dogs

\begin{tabular}{|l|l|l|}
\hline Analyzed dogs & Groups & Percentage \\
\hline \multirow{4}{*}{ Residence } & Indoors & 33.33 \\
\cline { 2 - 3 } & Outdoors & 33.33 \\
\cline { 2 - 3 } & Shelter & 33.33 \\
\hline \multirow{4}{*}{ Sex } & Females & 57 \\
\cline { 2 - 3 } & Males & 43 \\
\hline \multirow{4}{*}{ Age } & Up to 1.5 years & 7 \\
\cline { 2 - 3 } & $1.5-2$ years & 12 \\
\cline { 2 - 3 } & 2-8 years & 63 \\
\cline { 2 - 3 } & Over 8 years & 18 \\
\hline
\end{tabular}

luation of results, secondary inoculation, determination of antibiotic resistance.

1. Sampling. Samples were taken from the abdominal area of the dogs with a sterile cotton swab placed in the transport medium. Sterile transport medium with samples was stored according to the manufacturer's recommendations: $+4^{\circ} \mathrm{C}$ for up to 48 hours.

2. Primary inoculation of samples into the selective media. Samples from the transport medium are seeded on mannitol salt agar and incubated for 24-48 hours with a control (unseeded) Petri dish $+37^{\circ} \mathrm{C}$ thermostat.

3. Identification of the micro-organisms and evaluation of the results. After 24-48 hours incubation, Petri dishes are removed from the thermostat and those dishes in which bacterial growth is detected are selected for further examination. Also, the cultural properties were evaluated that can help differentiate the bacteria grown in the growth medium. Colony size, color, shape, and consistency, or even the ability of bacteria to ferment mannitol by changing the color of the medium, can be described.

4. Secondary inoculation. The found staphylococci are inoculated into Mueller Hinton agar to hold the culture and perform a biochemical study.

5. Determination of antimicrobial resistance. Staphylococcus spp. colonies with an optical density of 0,5 Mac Farland units, were inoculated into Mueller Hinton agar with a sterile cotton swab, antibiotic discs were placed according to established rules and incubated in a thermostat for 16-20 hours. At a temperature of $+37^{\circ} \mathrm{C}$.

As the bacterial culture grows, it is necessary to evaluate its purity. Smear of isolated bacterial colonies was performed and $t$ the smear was stained by the Gram method. The stained smear was microscopically immersed in an immersion system and the morphological properties of the bacteria are

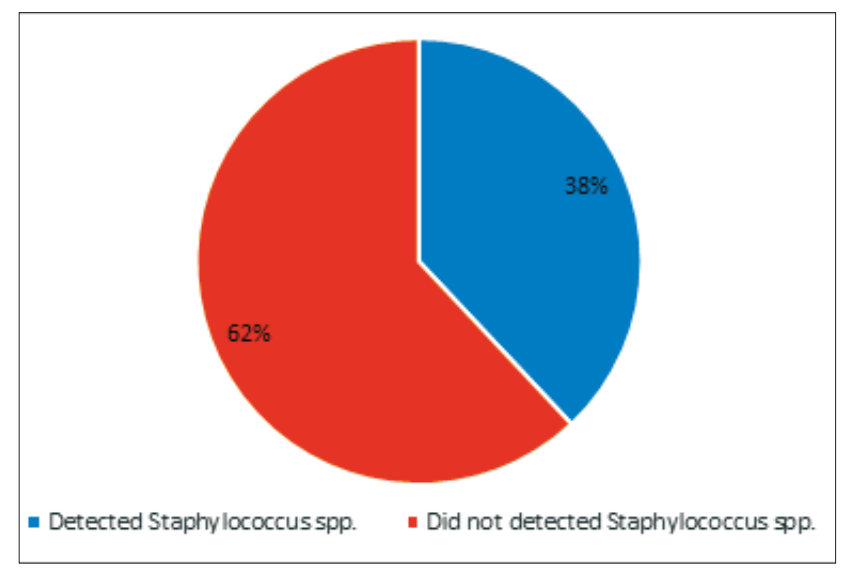

Figure 1. Staphylococcus spp. in analyzed samples $(\mathrm{N}=60)$ 
assessed: color, shape, size, and distribution.

After assessing the morphological and cultural characteristics of the cultured bacteria, studies of biochemical properties are performed to help more accurately identify grown bacterial colonies.

Staphylococcus spp. identification tests

Decomposition of mannitol. A sample from the transport medium was transferred to mannitol salt agar to assess the ability of the microorganisms to degrade mannitol. After $24-48$ hours at $+37^{\circ} \mathrm{C} S$. aureus bacteria grow $\mathrm{S}$-shaped on a solid medium, with bright and shiny colonies (smooth surface and edges) which are yellow due to the biochemical property of $S$. aureus to ferment mannitol to acids and change the color of the medium from pink to yellow.

Plasma coagulase test. Lyophilized rabbit plasma was used to determine this property. Isolated pure bacterial culture was added to a tube containing $0.5 \mathrm{ml}$ of lyophilized rabbit plasma. The sample was incubated for 24 hours at $+37^{\circ} \mathrm{C}$ thermostat. After incubation, plasma coagulation is monitored - if plasma coagulated, then the plasma coagulase test is positive and if did not - the micro-organism does not coagulate the plasma.

DNA testing. This test was performed to find out if the growing microorganism breaks down the DNA. The medium containing the DNA was prepared and inoculate the test culture with a microbiological loop and was incubated in a thermostat for 24 hours at $+37^{\circ} \mathrm{C}$. After incubation, 1 per cent HCL (Hydrochloric acid) solution was added to the control and pure culture. The test is considered positive when a clear area forms around the spotted colony and a gray area forms on the control plate.

\section{Results and their discussion}

60 dogs were included in this study, which were proportionally distributed according to their place of residence (Table 1) -33.3 per cent outdoors, 33.3 per cent indoors and 33.3 per cent in a shelter. It was observed that there were more female ( 57 per cent) than male (43 per cent).
A microbiological test was performed to detect Staphylococcus spp. growing on dog skin. In this study, staphylococci were detected in 23 samples (38 per cent) out of 60 samples, and spore rod-like microorganisms were detected in the remaining 37 samples (62 per cent) (Fig. 1). In a similar study, staphylococci were isolated from 203 (67.3 per cent) samples taken from 303 dog skin swabs [10].

Detection of the coagulase enzyme was performed in further analysis. The results showed that out of 23 cultivated Staphylococcus spp. coagulated plasma only eight ( 35 per cent) and the remaining 15 did not have this property (65 per cent). In a previous study [10], found 20 non-coagulation plasma staphylococcal species and only 3 coagulation plasma species in

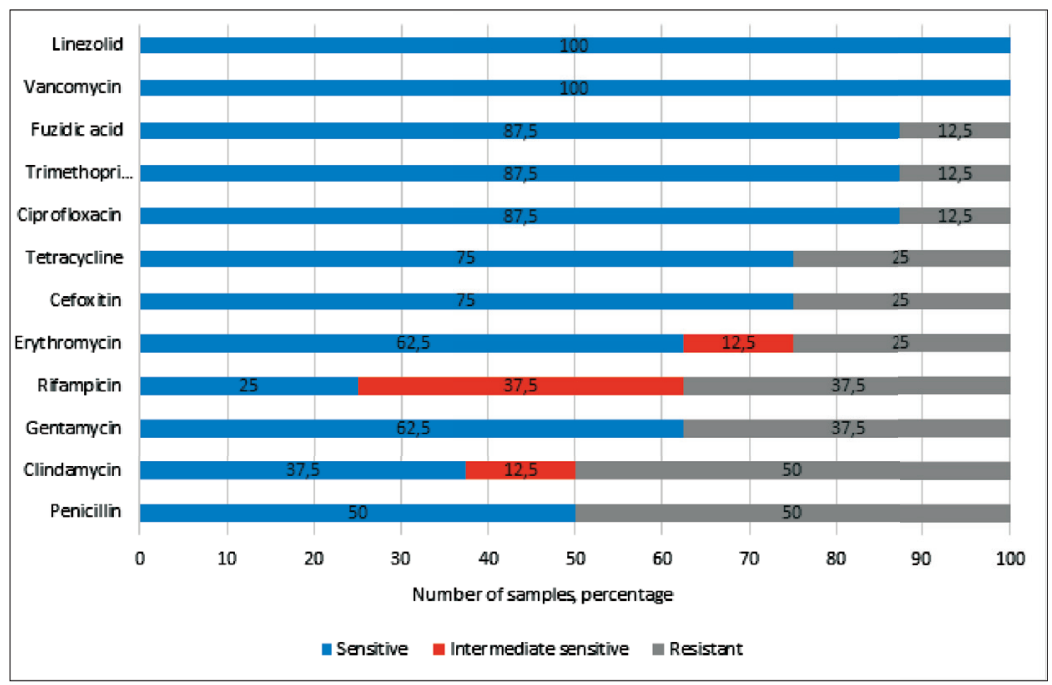

Figure 2. Antibiotic resistance of Staphylococcus aureus

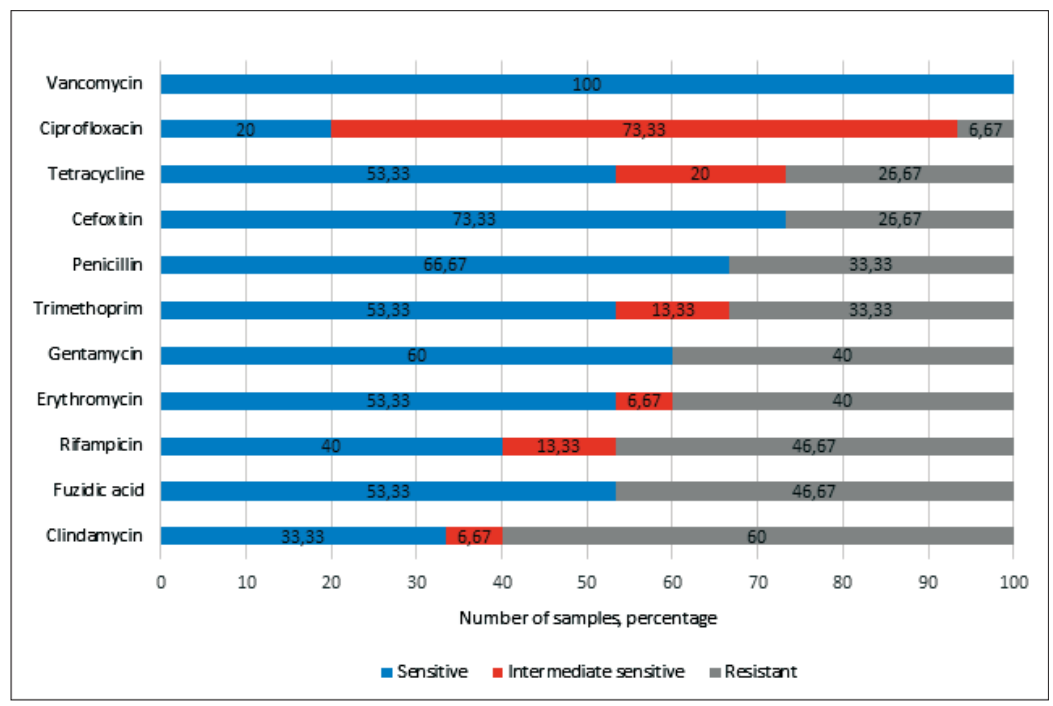

Figure 3. Non-coagulating Staphylococcus spp. antibiotic resistance 
samples removed from dogs and cats.

After selecting the appropriate antibiotics according to EUCAST, an antibiotic study was performed with plasma coagulation and non-plasma coagulation Staphylococcus spp. cultures. The results showed, all plasma coagulation cultures of $S$. aureus (Fig. 2) were sensitive to linezolid (100 per cent) and vancomycin (100 per cent), cefoxitin ( 75 per cent) and tetracycline (75 per cent) were equally sensitive and rifampicin was the least sensitive ( 25 per cent). The vast majority of cultures were resistant to penicillin (50 per cent) and clindamycin (50 per cent), were slightly less resistant of gentamycin (37.5 per cent) and rifampicin (37.5 per cent). On average, ciprofloxacin ( 87.5 per cent), clindamycin (12.5 per cent) and erythromycin (12.5 per cent) were equally sensitive.

Among non-coagulating Staphylococcus spp. strains (Fig. 3), it was observed that all strains were sensitive to vancomycin (100 per cent), tetracycline (53.33 per cent), fusidic acid (53.33 per cent) and trimethoprim/ sulfamethoxazole (53.33 per cent) were equally sensitive. And the lowest level of sensitivity was ciprofloxacin ( 20 per cent). Cultures were equally resistant to fusidic acid (46.67 per cent) and rifampicin (46.67 per cent), most resistant to clindamycin (60 per cent) and least resistant to ciprofloxacin (6.67 per cent). The moderately most sensitive were cefoxitin (73.33 per cent), rifampicin (13.33 per cent) and trimethoprim/sulfamethoxazole (13.33 per cent), and the least sensitive were clindamycin (6.67 per cent) and erythromycin (6.67 per cent).

In this study was found 100 percent of plasma coagulation Staphylococcus spp. in samples collected from dogs indoors. In dogs living outdoors, plasma coagulation strains were mostly detected at 85.71 per cent, while non-coagulation plasma levels were almost 6-fold lower at only 14.29 per cent. These results may be influenced by the fact that dogs living outdoors are tethered that the host rarely cleans and disinfects, thus creating the

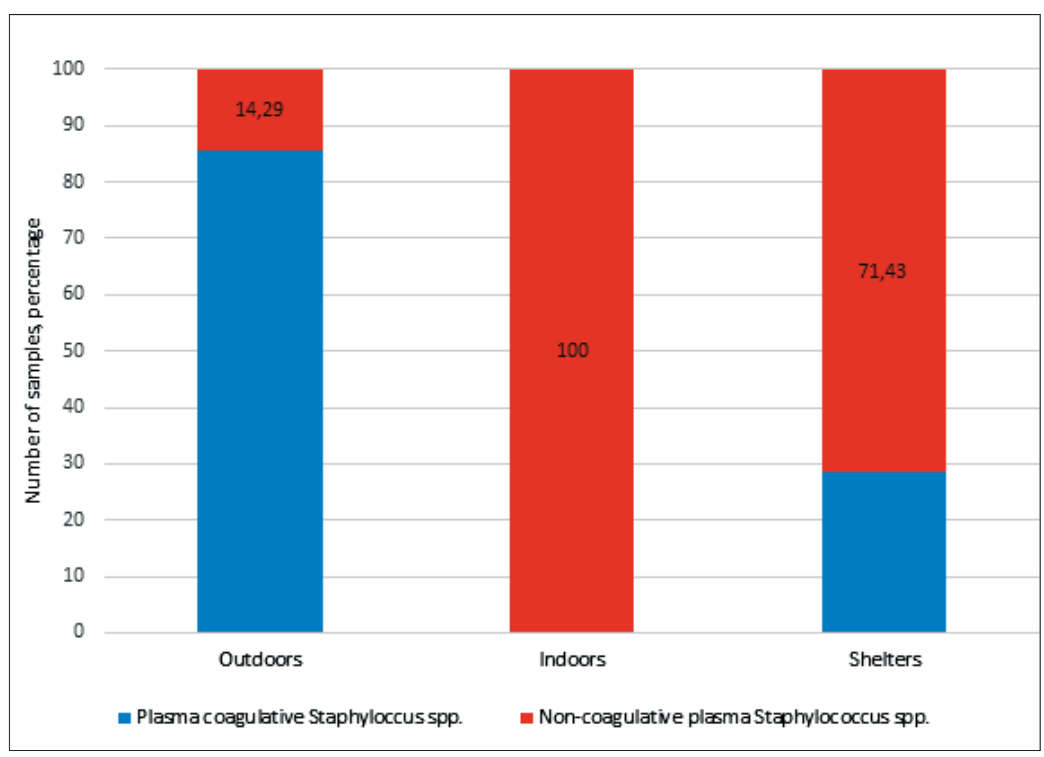

Figure 4. Plasma coagulating and non-coagulating Staphylococcus spp., according to the dog's place of residence opportunity for microorganisms to reproduce. Shelter dogs had 74.43 per cent more non-coagulating plasma on their skin than 28.57 per cent of non-coagulating plasma. This result may have been influenced by the fact that the dogs in the shelters are supervised by veterinarians and their pens are cleaned daily (Fig. 4.). A similar study [5] showed that nine (27.3 per cent) staphylococci were resistant to methicillin and 34 out of 39 ( 87 per cent) sturgeons were found in an animal primary care clinic.

\section{Conclusion}

Non-coagulation plasma staphylococci were the most common among dogs living indoors and plasma coagulation among dogs living outdoors. All staphylococci found on the skin of dogs, regardless of where they lived, were susceptible to vancomycin. Staphylococci isolated from pet dog skin were resistant to clindamycin, fusidic acid, linezolid, staphylococci isolated from field dog skin were resistant to clindamycin, rifampicin, and gentamicin and were protected from clindamycin.

\section{References}

1. Barer RM, Irving W, Swann A, Perera N. Medical Microbiology: A Guide to Microbial Infections: Pathogenesis, immunity, laboratory investigation and control. Elsevier 2018, 19th edition, 1-760.

2. Cuscó A, Belanger JM, Gershony L, IslasTrejo A, Levy K, Medrano JF, Sánchez A, Oberbauer AM, Francino O. Individual signatures and environmental factors shape skin microbiota in healthy dogs. Microbiome 2017a;5(1):139.

https://doi.org/10.1186/s40168-017-0355-6

3. Cuscó A, Sánchez A, Altet L, Ferrer L, Francino O. Individual Signatures Define Canine Skin Microbiota Composition and Variability. Front Vet Sci 2017b;6(4):6. https://doi.org/10.3389/fvets.2017.00006

4. Čaplinskas S., Andziukevičiūtė J. Mikroorganizmų atsparumas ir infekcijos. Tyla prieš audrą. Lietuvos bendrosios praktikos gydytojas. 2012;16(8):546-559.

5. Eckholm NG, Outerbridge CA, White SD, Sykes JE. Prevalence of and risk factors for 
isolation of meticillin-resistant Staphylococcus spp. from dogs with pyoderma in Northern California, USA. Vet Dermatol 2013;24(1):154-61.

https://doi.org/10.1111/j.1365-3164.2012.01051.x

6. Garbacz K, Piechowicz L, Podkowik M, Mroczkowska A, Empel $\mathrm{J}$, Bania J. Emergence and spread of worldwide Staphylococcus aureus clones among cystic fibrosis patients. Infect Drug Resist 2018; 22(11):247-255.

https://doi.org/10.2147/IDR.S153427

7. Grice EA, Segre JA. The skin microbiome. Nat Rev Microbiol 2011;9(4):244-53. https://doi.org/10.1038/nrmicro2537

8. Hotterbeekx A, Kumar-Singh S, Goossens H, Malhotra-Kumar $\mathrm{S}$. In vivo and in vitro Interactions between Pseudomonas aeruginosa and Staphylococcus spp. Front Cell Infect Microbiol 2017; 3(7):106.

https://doi.org/10.3389/fcimb.2017.00106

9. Le Loir Y, Baron F, Gautier M. Staphylococcus aureus and food poisoning. Genet Mol Res 2003;31(1):63-76.

10. Ma GC, Worthing KA, Ward MP, Norris JM. Commensal Staphylococci Including Methicillin-Resistant Staphylococcus aureus from Dogs and Cats in Remote New South Wales, Australia. Microb Ecol 2020;79(1):164-174.

https://doi.org/10.1007/s00248-019-01382-y

11. Tong SY, Davis JS, Eichenberger E, Holland TL, Fowler VG Jr. Staphylococcus aureus infections: epidemiology, pathophysiology, clinical manifestations, and management. Clin Microbiol Rev 2015;28(3):603-61.

https://doi.org/10.1128/CMR.00134-14

12. Zamarian V, Catozzi C, Cuscó A, Stefanello D, Ferrari R, Ceciliani F, Francino O, Sánchez A, Grieco V, Zani D, Talenti A, Crepaldi P, Lecchi C. Characterization of skin surface and dermal microbiota in dogs with mast cell tumor. Sci Rep 2020;28(1):12634.

https://doi.org/10.1038/s41598-020-69572-0

\section{PLAZMĄ KOAGULIUOJANČIŲ IR \\ NEKOAGULIUOJANČIU STAPHYLOCOCCUS SPP. IŠSKYRIMAS NUO ŠUNŲ ODOS BEI JŲ ATSPARUMAS ANTIBIOTIKAMS \\ Ž. Maželienė, A. Aleksandravičienė, A. Petrauskaitė, I. Viliušiené, D. Šakiené}

Raktažodžiai: Staphylococcus aureus, plazmos nekoaguliuojantys stafilokokai, paplitimas, atsparumas antibiotikams.

Santrauka

Stafilokokai yra žmonių ir gyvūnų gleivinès paviršiaus bei odos komensalai, kurie gali sukelti ịvairias infekcijas, tokias kaip odos pūlinès infekcijos, išorinis otitas, pioderma, šlapimo takų infekcijos ir pooperacinès infekcijos. Šunų oda yra vienas iš šių gyvūnų apsauginių barjerų, tačiau ant jos gali būti įvairių mikroorganizmų, tarp jų ir stafilokokų. Daugumoje atliktų tyrimų buvo lyginami plazmą koaguliuojantys ir nekoaguliuojantys Staphylococcus spp. pagal šuns veislę, lytị, kailio ilgị. Šio tyrimo tikslas - nustatyti plazmą koaguliuojančius ir nekoaguliuojančius Staphylococcus spp. nuo šunų odos bei jų atsparumą antibiotikams pagal jų gyvenamą vietą. Daugiau nei pusejje tirtų mėginių buvo aptikti stafilokokai, iš kurių trečdalis - plazmą koaguliuojantys, o likusieji du trečdaliai - plazmos nekoaguliuojantys. Plazmos nekoaguliuojančių stafilokokų daugiausiai išaugo gyvenantiems namuose, o plazmą koaguliuojančių - gyvenantiems lauke šunims. Staphylococcus aureus buvo daugiausiai atsparūs penicilinui ir klindamicinui, o plazmos nekoaguliuojančių atsparumas pasireiške fuzido rūgščiai.

Adresas susirašinèti: zaneta.mazeliene@go.kauko.lt

Gauta 2021-10-26 